Research Publishing

Academy (RPA)

London, United Kingdom (UK)

\section{JIBM}

Journal of International Business and Management (JIBM) Journal Homepage: https://rpajournals.com/jibm

\title{
Influences of Organizational Factors on Organizational Capability for Innovation: An empirical Study from Vietnamese Firms
}

\author{
Le Ba Phong ${ }^{1 *}$ \\ Ha Thanh Tung ${ }^{2}$ \\ Hanoi University of Industry, Bactuliem, Hanoi, Vietnam ${ }^{1,2}$
}

\begin{abstract}
Given the key role of organizational factors for improving firm's innovation capability, the purpose of this study is to explore the level of influence of organizational factors namely transformational leadership (TL), human resource management (HRM) practice and collaborative culture on two aspects of organizational innovation capability namely product and process innovation. The paper has developed a proposal research model and applied Structural Equation Modeling (SEM) to test research hypotheses using data collected from 168 participants in 51 Vietnamese firms. The findings of this study confirm the significant impacts of key organizational factors on firm's capabilities for product and process innovation. Especially, the empirical findings reveal that TL has a greater impact on process innovation. In contrast, collaborative culture has more significant influence on product innovation. The findings of this study have significantly contributed to increasing the insight of the link between key organizational factors and specific aspects of innovation capability. Moreover, it provides a specific and effective pathway for Vietnamese firms to pursuit and foster each specific aspect of organizational capability for innovation.
\end{abstract}

Keywords: Transformational Leadership, HRM Practice, Collaborative Culture, Product Innovation, Process Innovation, Innovation Capability

*Corresponding author: Le Ba Phong; Email: lebaphong@haui.edu.vn DOI: https://doi.org/10.37227/JIBM-2021-05-756

\section{Introduction}

In recent years, Vietnam has been generally known as a dynamic and emerging market with a relatively high and stable economic growth rate, approximately $7 \%$. Especially, the economic growth rate of Vietnam still reached $2.91 \%$ and became one of the few countries with the best economic growth in the world in 2020 despite many difficulties and challenges of global economy and major nations due to the negative effects of Covid-19 pandemic (Le Ba, 2021). However, to ensure the Vietnamese economy continues to achieve growth and development stably, it requires Vietnamese firms to constantly improve their innovation capability in order to adapt well to the rapid changes of technology, socio-economic environment, competitive pressure, and increasing diversity of customer needs (Phong et al., 2018; Gui et al., 2021; Than et al., 2021).

Improving innovation capability is regarded as an optimal strategy for firms to achieve competitive advantages through cost reduction, quality improvement, and unique product/services development. (Yang et al., 2018; Le \& Lei, 2019; Son et al., 2019). Accordingly, many Vietnamese firms attempt to identify appropriate and effective pathways to successfully innovate. Yet they are still imitators and are struggling to really become innovators due to lack of understanding on the key role of organizational factors such as transformational leadership (TL) style (Phong \& Son, 2020; Le 
\& Le, 2021; Ha \& Le, 2021; Lei et al., 2021a), human resource management (HRM) practices (Lei et al., 2021b; Than et al., 2021), and collaborative culture (Lei et al., 2017; Nguyen et al., 2019; Le et al., 2020) in improving innovation. Moreover, current literature pays little attention to the antecedents of specific aspects of firm's innovation capability (Yang et al., 2018; Le, 2020; Le et al., 2020). Given this context, to increase the understanding on the effects of strategic organizational factors on innovation capability, the purpose of this study is to examine the influence of TL, HRM practices, and collaborative culture on organizational capability for product and process innovation. This study is expected to bring deeper insight of the relationship between key organizational factors on innovation capability of Vietnamese firms by following motives.

First, prior studies supposed that among different leadership styles, TL has emerged as one of the most influential leadership styles by which CEOs and managers can practice to improve organizational innovation capability and key outcomes (Le \& Lei, 2018a,b; Phong \& Son, 2020; Son et al., 2020). However, knowledge of the relationship between TL and specific aspects of innovation capability namely product and process innovation remains underdeveloped and insufficient, especially in the context of emerging and developing countries like Vietnam (Le \& Lei, 2019; Gui et al., 2021; Le \& Le, 2021). To fill this research gap, this study will clarify the effect of TL on product and process innovation of Vietnamese firms by posing the first research question (RQ).

RQ1. Does TL positively affect product and process innovation capability?

Second, HRM practices play an important role in creating positive motives to encourage the firm's abilities and practices for promoting innovation capability (Cho et al., 2019; Iqbal et al., 2020). Specifically, Chen and Huang (2009) advocated that strategic HRM function can effect and alter employees' attitudes, capacities and behaviors to attain organizational goals. However, Than et al. (2021) argued that despite substantial progress made in the current literature to explain for the significant influences of HRM practices on innovation, the precise mechanisms underlying the relationship between HRM practices and specific aspects of innovation remain poorly understood. To address this vacancy and the understanding on the effect of HRM practices on aspects of innovation capability, this study poses the second research question as follows.

RQ2. Do HRM practice have different positive effects on product and process innovation capability?

Third, organizational culture refers to the shared values, beliefs or perceptions which provide norms of expected behaviors for employees to follow (Yang et al., 2018; Le et al., 2020). It is widely accepted as a potential factor that plays the increasingly important role in nurturing and fostering innovation capability for firms (Hogan \& Coote, 2014; Tian et al., 2018). However, Le et al. (2020) indicated that considered the core values of organizational culture, collaborative culture emerges as one of the most important antecedents to stimulate KS among employees and improve innovation capability for firms. However, it is still limited knowledge on the relationship between collaborative culture and different types of organizational innovation (Yang et al., 2018; Le et al., 2020). For such context, the third research question is posed.

RQ3. Does collaborative culture positively affect product and process innovation capability?

To fill research gaps addressed above, this study develops an integrated research model to quantify the effects of TL, HRM practices, and collaborative culture on innovation capability of Vietnamese firms for product and process innovation.

This study applies structural equations modeling (SEM) to examine the correlation between the research variables in the proposal research model based on the data collected from 168 participants in 51 manufacturing and service firms in Vietnam. This study is expected to provide theoretical and practical initiatives on leadership, HRM, and organizational culture to pursuit and improve innovation capability for Vietnamese firms under the pressure of competition and economic integration into the region and the world. 


\title{
Literature Review and Hypotheses Development
}

\author{
Theories of TL, HRM practice, collaborative culture and innovation capability
}

\section{Innovation capability}

Innovation capability is defined as the firm capabilities of creating new products, services, work processes, and management procedures to gain an organizational competitive advantage (Le \& Lei, 2019; Lei et al., 2021a,b). According to Le and Lei (2019), innovation capability is classified into various categories, however, product and process innovation are recognized as two fundamental types that reflect two critical capabilities of innovation in complex and rapidly changing business environments. Product innovation involves firms' capability of providing differentiated or new products/services in the market to acquire customers' satisfaction. Process innovation involves firms' capability of providing a better process than current operation to get better performance (Le \& Lei, 2019). Innovation capability is a principal driver of economic development and plays a pivotal role in competition at both the national and firm levels (Hogan \& Coote, 2014; Than et al., 2021). Le and Lei (2019) indicated that academic discussion recent years around the phenomenon of innovation capability because developing innovation capability help firms of all industries to guarantee their success in the markets. As a result, to clarify the influence of key organizational factors, this study focuses on investigating the influences of TL, HRM practices, and collaborative culture on these two aspects of innovation.

\section{Transformational leadership}

Bass (1999) defined transformational leadership (TL) with four characteristics including (1) idealized influence: ability to provide a vision and perception of mission, instilling pride, gaining respect and trust); (2) intellectual stimulation: ability to promote intelligence, rationality and attentive problem solving); (3) inspirational motivation: interested in communicating high expectations, using symbols to focus efforts, expressing important purposes in simple ways); and (4) individualized consideration: interested in personal attention, treating each employee individually, coaching and advising. The theory of TL has attracted much observation from scholars and emerged as one of the most powerful leadership theories (Le \& Lei, 2017; Le \& Lei., 2018a,b,c; Van et al., 2018; Hui et al., 2018; Le et al., 2018a,b; Phong et al., 2018; Lei et al., 2019a,b,c,d; Sengphet et al., 2019; Le \& Tran, 2019; Ha et al., 2019). Consequently, investigating the relationship between TL and innovation capability of Vietnamese firms will enrich the understanding and knowledge of new leadership style and innovation management in Vietnamese context.

\section{Human resource management practice}

HRM practice is defined in some different ways. Delery and Doty (1996) considered HRM practices as a set of internally consistent policies and practices designed and implemented to ensure that a firm's human capital contributes to the achievement of its business objectives. According to Martínde Castro et al. (2013), HRM practice relates to specific practices, formal policies, and philosophies that are designed to attract, develop, motivate, and retain employees who ensure the effective functioning and survival of the organization. Aman et al. (2018) seen HRM practice as those practices which an organization develops for recruiting, retaining and securing most capable and potential candidates for running its operations successfully. Against this backdrop, we concluded that HRM practices are the formal policies and actual actions designed and applied by organizations to attract, develop, motivate, and retain most capable and potential employees for creating human resourcebased competitive advantage and achieving organizational goals.

\section{Collaborative culture}

Organizational culture is perceived as a critical factor and antecedent of innovation because it lies at the heart of organizational innovation (Tian et al., 2018; Le et al., 2020). Collaborative culture refers to core cultural values characterized by long-term vision and advance management of the change, 
team-work, communication, risk assumption, respect and empowerment and promoting the knowledge of individuals (Yang et al., 2018; Lei et al., 2019a,b; Le et al., 2020). It is supposed containing the potential cultural values which create the appropriate conditions to promote innovation for firms (Yang et al., 2018; Le et al., 2020). By focusing on collaboration-oriented cultural values, this study will investigate the effects of collaborative culture on innovation in two facets of product and process innovation capability.

\section{The effect of organizational factors on innovation capability}

\section{The influences of TL on innovation capability}

Leadership is usually perceived a key force in creating appropriate condition conducive to firms' innovation competence and key organizational outcomes (Le Ba, 2018; Ab Rahman \& Jantan, 2020; Phong \& Son, 2020). So many prior studies have investigated the decisive and positive influence of leadership on innovation. In particular note, scholars highlight the significant impact of TL on innovation capability (Van et al., 2018; Le \& Lei, 2019; Le, 2020: Lei et al., 2020: Le Ba, 2021). For example, Van et al. (2018) asserted that transformational leaders can foster organizational innovation capability by forming and stimulating a learning environment in organizations. This is very beneficial for adding new knowledge and information among employees for improving innovation ability. According to Le (2020) and Lei et al. (2020) in a positive environment of honesty and altruism led by transformational leaders, employees are not only more committed to share their knowledge with their colleagues but also more likely to have better psychological capital (such as higher optimism and self-efficacy) to present new ideas, and novel ways of doing things that challenge the status quo for organizational innovation. Le Ba (2021) supposed that TL practice acts as an instrument in shaping and instilling an innovation culture that encourages creativity, risk taking, and nurtures firm's innovation competency. These allow firms successfully improve frugal innovation capability due to bring employees a good feel and readiness to find innovative solutions to overcome difficulty. In particular note, Le and Lei (2019) showed the positive effect of TL on product and process innovation directly or indirectly via mediating role of knowledge sharing activities. Based on these discussions, the first hypothesis is proposed (Figure 1).

Hla.b: TL is positively related to product and process innovation capability

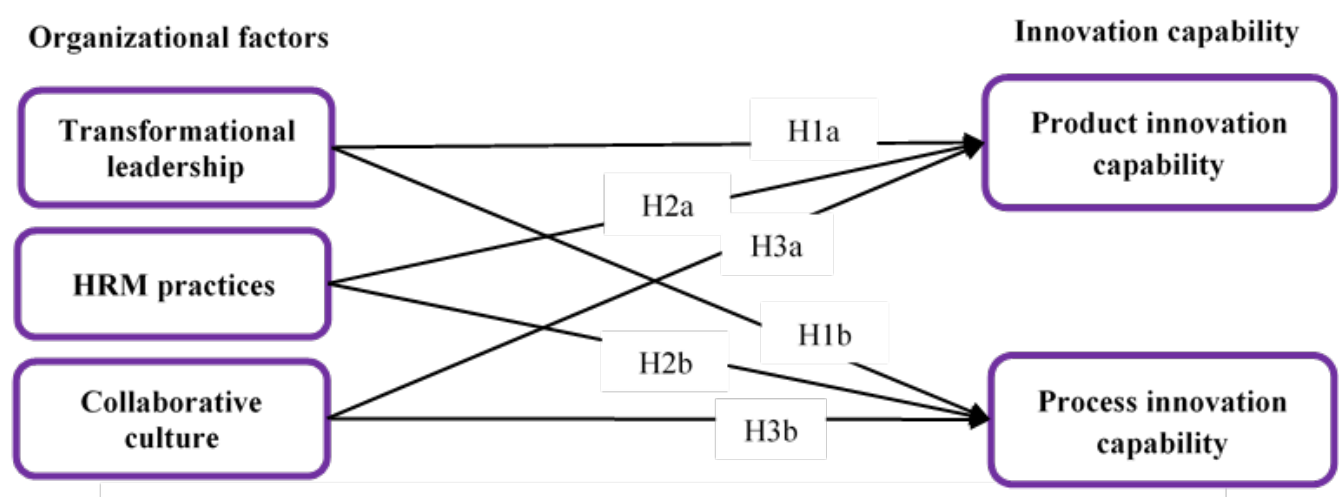

Figure 1. Proposed research model

\section{The influences of HRM practice on innovation capability}

Regarding influence of HRM practice, many studies in the growing literature on HRM practices have shown its positive and significant impacts on firm's capability for innovation. Indeed, Scarbrough (2003) argued that HRM practice enables firms to promote creative ideas, generate innovative approaches, and take advantage of new opportunities for improving management processes and developing new products/services. Chen and Huang (2009) advocated that HRM functions can effect and alter employees' attitudes, capacities, and behaviors to attain organizational goals. This gives assistance to nurture and create the necessary conditions as well as catalysts for employees to develop 
innovation activities. According to Lei et al. (2021a), HRM practices are perceived as the key organizational mechanisms that help firms to match their employees' abilities with their strategic objectives such as exploitative and exploratory innovations. Their finding indicated that HRM practices can be an effective solution for firms to pursue and foster innovation capabilities such as exploitative and exploratory innovation. Recently, Than et al. (2021) argued that organizational innovation capability is mainly originated from process of sharing knowledge among employees, by which, HRM practices help to foster knowledge sharing activities, and therefore, foster firm's capability for exploitative and exploratory innovation. These arguments support the positive effect of HRM practices on innovation capability. However, according to authors' knowledge, little study has investigated the correlation between HRM practices and innovation capability in term of product and process innovation, so following hypothesis are posed:

H2a.b. HRM practices significantly predict product and process innovation capability

\section{The influences of collaborative culture on innovation capability}

Collaborative culture is recently emerged as one of the most important types of organizational culture that have positive impacts on innovation capability of organizations. Indeed, Ahmed et al. (2016) indicated that collaborative culture acts as an important context factor in boosting knowledge sharing activities which eventually enhances the creativity and innovation among employees in the organization. Kumar et al., (2016) found that increasing the level of relationship and collaboration is a very important solution to promote the organizational capability to adjust the existing processes and new product development. Le et al. (2020) pointed out that collaborative culture facilitates creativity, empowerment, and change which are vital to drive innovation. Thus, building collaborative relations is one of important means to develop innovation capabilities. Their empirical findings showed that developing a collaborative culture is a smart choice for improving organizational capability for radical and incremental innovation Specially, according to Yang et al. (2018), collaborative climate itself has been found to be related to innovative and creative outcomes. Yang et al. (2018) argued that the successful degree of innovation mainly determined by the degree of collaboration and processes of sharing knowledge among employees. Their findings showed that collaborative culture directly and indirectly affects firm's product and process innovation capability via mediating role of knowledge sharing. Although the positive effect of collaborative culture on innovation is obvious (Le et al., 2020), literature on how collaborative culture induces positive impacts on product and process innovation is still sparse and limited (Yang et al., 2018). The following hypotheses are, therefore, to propose:

H3a.b: Collaborative culture positively predicts product and process innovation.

\section{Sample and data collection}

\section{Research Methodology}

Vietnam is a transitioning and developing country where firms have made a lot of effort to improve their innovation capability. Many scholars suggested the need of investigating the factors that successfully affect innovation of firms in developing countries like Vietnam (Nguyen et al., 2018; Lei et al., 2021a,b). Thus, this study is carried out through the data collected from firms located in Vietnam. The paper used convenient sampling method to collect data from both manufacturing and service firms in Hanoi province, Vietnam. We communicated with representatives of these firms who mainly worked in departments of HRM by phone or make personal visits to explain the purpose of the research, and ask for their assistance in collecting data. The respondents need to be vice managers, head of departments, team leaders to ensure having full understanding on firm's business situation. We used the measurement items that adapted from existing scales in the literature to develop the initial list of items. We then conducted a pilot test based on in-depth interviews with five outstanding academic scholars and 35 participants from three firms to refine the questionnaire and align with the Vietnamese context. In the formal data collection, this study sent 300 questionnaires to the representatives of 51 firms and received 215 ones, among which 168 ones are valid, with a $56.0 \%$ valid rate. 


\section{Variable measurement}

To ensure the validity and reliability of the study, the variables were measured using items developed and employed in previous studies. All items were measured via five-point Likert-type scales ranging from " 1 " (strongly disagree) to " 5 " (strongly agree) or from " 1 " (strongly unwilling to) to 5 (strongly willing to). This study uses eight items adapted from the study of Lei et al. (2021b) to measure TL style of leaders. This study used six items adapted from the study of Camelo-Ordaz et al. (2011) to measure the current state of HRM practices of firms. For measuring innovation capability, this study used 11 items adapted from the research of Yang et al. (2018) to measure product innovation (six items) and process innovation (five items). Finally, this study used eight items from Le et al.'s (2020) study to measure collaborative culture of firms (see Appendix 1).

\section{Data Analysis and Results}

\section{Measurement model}

We first tested the reliability of the measures of the constructs by examining the individual Cronbach's alpha $(\mathrm{C} \alpha)$ coefficients, which ranged from 0.94 to 0.97 and were all higher than the recommended level of 0.7 (Nunnally and Bernstein, 1994). We then performed confirmatory factor analysis (CFA) to assess the convergent and discriminant validity of the overall measurement model. We evaluate the convergent validity as recommended by Hair et al. (2006). Table 1 shows the model met the Hair et al.'s (2006) convergent validity criteria because (1) all factor loadings range from 0.77 to 0.96 (larger than 0.6; $p<0.001$ ); (2) CR values range from 0.94 to 0.97 (higher than 0.7); and (3) the AVE values range from 0.69 to 0.88 (greater than 0.5).

Table 1. Confirmatory factor analysis and scale reliability of measurement model

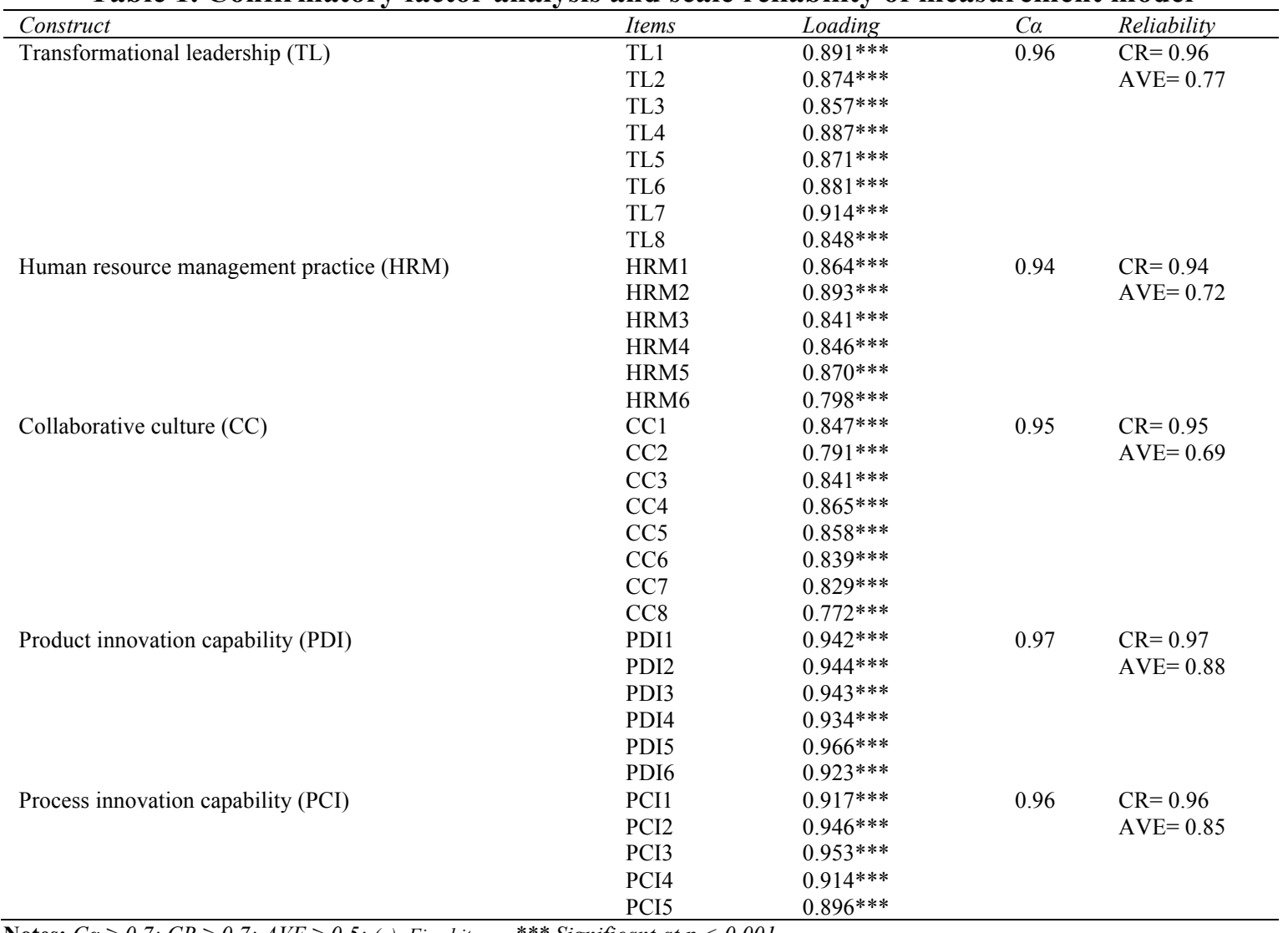

Notes: $C \alpha \geq 0.7 ; C R \geq 0.7 ; A V E \geq 0.5 ;$ (-): Fixed items; *** Significant at $p<0.001$. 
Discriminant validity is the degree to which factors that are supposed to measure a specific construct do not predict conceptually unrelated criteria (Fornell and Larcker, 1981). This study used Fornell and Larcker's (1981) measure of AVE to assess discriminant validity (Table 2).

Table 2. Descriptive statistics and discriminant validity

\begin{tabular}{|c|c|c|c|c|c|c|c|}
\hline Constructs & Mean & S.D & $T L$ & $H R M$ & $C C$ & $P D I$ & $P C I$ \\
\hline Transformational leadership (TL) & 3.43 & 0.61 & 0.87 & & & & \\
\hline Collaborative culture (CC) & 3.37 & 0.55 & $0.81 * * *$ & $0.81 * * *$ & 0.83 & & \\
\hline Process innovation capability (PCI) & 3.77 & 0.70 & $0.80 * * *$ & $0.74 * * *$ & $0.79 * * *$ & $0.77 * * *$ & 0.92 \\
\hline
\end{tabular}

$$
\text { Notes: S.D: standard deviation; Diagonal elements (in bold) are the square root of the AVE. }
$$

The discriminant validity of the research instrument was assessed by comparing the square root of the AVE with the correlations among the latent variables. Table 2 shows that the square root of AVE for each construct (diagonal elements in bold) is greater than the correlations among constructs in the model. It, therefore, provided strong support for the construct reliability, as well as for the convergent and discriminant validity of the scales.

Regarding the satisfactory of measurement model, Table 3 shows that all fit indices of the measurement model were satisfactory; thus, the model fit the data.

Table 3. Overall fit index of the CFA model

\begin{tabular}{lcc}
\hline Fit index & Scores & Recommended threshold value \\
\hline Absolute fit measures & & \\
CMIN/df & 1.389 & $\leq 2^{\mathrm{a}} ; \leq 5^{\mathrm{b}}$ \\
GFI & 0.819 & $\geq 0.90^{\mathrm{a}} ; \geq 0.80^{\mathrm{b}}$ \\
RMSEA & 0.048 & $\leq 0.08^{\mathrm{a}} ; \leq 0.10^{\mathrm{b}}$ \\
Incremental fit measures & & \\
NFI & 0.911 & $\geq 0.90^{\mathrm{a}} ;$ \\
AGFI & 0.789 & $\geq 0.90^{\mathrm{a}} ; \geq 0.80^{\mathrm{b}}$ \\
CFI & 0.973 & $\geq 0.90^{\mathrm{a}} ;$ \\
\hline
\end{tabular}

Notes: a: Acceptable; b: Marginal; RMSEA: root mean square error of approximation; GFI: goodness of fit index; CFI: comparative fit index; NFI: normed fit index; AGFI: adjusted goodness of fit index.

\section{Results and Analysis}

This study performs structural equation modeling to test the hypotheses using AMOS 22.0 and maximum likelihood estimation techniques.

Findings in Figure 2 and Table 4 show that all the standardized path coefficients of direct effects are found to be significant and in line with the stated hypothesis. Specifically:

Table 4. Results of the relationship among the constructs

\begin{tabular}{lllll}
\hline Hypothesis & Relationship & Beta & t-value & Results \\
\hline H1a & TL $\rightarrow$ Product innovation capability & $0.237^{* *}$ & 2.711 & Supported \\
H1b & TL $\rightarrow$ Process innovation capability & $0.401^{* * *}$ & 4.537 & Supported \\
H2a & HRM practices $\rightarrow$ Product innovation capability & $0.173^{*}$ & 1.914 & Supported \\
H2b & HRM practices $\rightarrow$ Process innovation capability & $0.179^{* *}$ & 1.985 & Supported \\
H3a & CC $\rightarrow$ Product innovation capability & $0.482^{* * *}$ & 4.431 & Supported \\
H3b & CC $\rightarrow$ Process innovation capability & $0.330^{* *}$ & 3.082 & Supported \\
\hline \multicolumn{5}{c}{ Notes: $* * * p<0.001 ; * * p<0.05 ;$ and $* p<0.1$ level. } \\
\end{tabular}




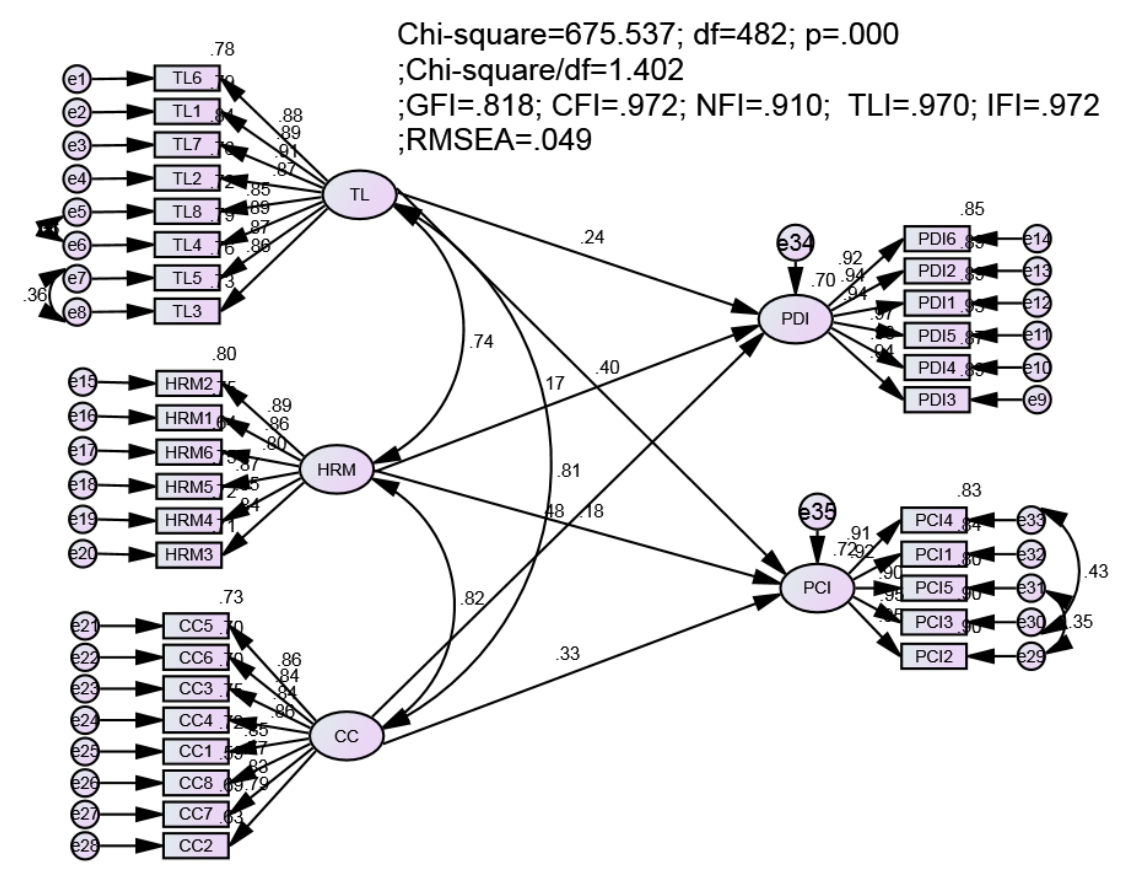

Figure 2. Path coefficients of the structural model

Hypothesis H1a.b relating to TL-innovation capability relationship, results in the Table 4 shows the effects of TL on process innovation capability $(\beta=0.401 ; p<0.001)$ is greater than its effects on product innovation capability $(\beta=0.237 ; p<0.05)$. Hypotheses H1a and H1b are supported.

Referring H2a.b results in the Table 4 indicates that HRM practices have positive impacts on product innovation $(\beta=0.173 ; p<0.1)$ and process innovation $(\beta=0.179 ; p<0.05)$. However, the effects of HRM practice on product and process innovation are not significantly different. Hypotheses $\mathrm{H} 2 \mathrm{a}$ and $\mathrm{H} 2 \mathrm{~b}$ are confirmed.

Finally, H3a.b relating to the relationship between collaborative culture and innovation capability, the empirical findings indicate that influence of collaborative culture on product innovation capability $(\beta=0.482 ; p<0.001)$ is significant and greater than its effect process innovation capability $(\beta=0.330 ; p<0.05)$. Hypotheses $\mathrm{H} 3 \mathrm{a}$ and $\mathrm{H} 3 \mathrm{~b}$ are also supported.

\section{Discussions}

Innovation capability is generally acknowledged by scholars and practitioners as a crucial competitive enabler for firms to remain competitive advantage and overcome the key rivals (Yang et al., 2018; Le \& Lei, 2019; Tran \& Le, 2019). The main goal of this study is to investigate the influence of key organizational factors on organizational innovation capabilities. The findings of this study have revealed that transformational leadership, HRM practices and collaborative culture are the key antecedents to foster firm's innovation capability in term of product and process innovation. The assessment of the hypotheses developed in this paper significantly increase the knowledge of the effective pathway by which CEOs and managers might follow make the right decisions to stimulate specific aspects of innovation capability. In general, the findings of this paper has significantly contributed to expanding both theoretical and practical understanding in the field of leadership, HRM, organizational culture, and innovation management by following reasons.

First, TL is seen as one of the most typical and appropriate leadership styles for managers to increase organizational innovation capability and other outcomes (Le Ba, 2018; Le \& Lei, 2019; Ahmad, Ali, Jantan, Bowyer, \& Reaz, 2020). However, TL-innovation relationships have received little research attention (Le, 2020). Moreover, Le and Lei (2019) indicated that lack of study has 
investigated the effect of TL on specific aspects of innovation capability such as product and process innovation. Thus, to bridge the research gap, this study proposes a research model to link TL and two aspects of innovation capability. The empirical findings have verified the positive impacts of TL on innovation capabilities, and revealed that TL is more associated with process innovation in comparison with its impacts on product innovation. These findings imply that, under leading by transformational leaders, firms can create and establish a better process of operation to get better performance compared to key competitors.

Second, although HRM practices are considered driving force for firms to enhance innovation capability, little study has investigated the mechanism of how HRM practices significantly affect innovation capability (Than et al., 2021; Lei et al., 2021a), especially in term of product and process innovation. As a result, by testing and confirming the significant and positive impacts of HRM practices on two specific aspects of innovation namely product and process innovation, the findings of this study significantly contribute to theoretical development of a conceptual model that clearly explain the relationships among HRM practices and innovation capability in the context of Vietnamese firms.

Finally, Yang et al. (2018) and Le et al. (2020) commented that collaboration of individuals can be one of the most important solution for firms to bring the willingness to innovate. However, empirical study on the collaborative culture-innovation relationship is still lacking (Yang et al., 2018; Le, 2020). Moreover, organizational culture is well-known as an important organizational factor that have considerable influences on strategy and capability of firms to innovate (Yang et al., 2018). However, "what kind of organizational culture is conducive to innovation?" (Le et al., 2020) is still an important issue that needs to be clarified. By examining the effects of collaborative culture on product and process innovation, the empirical findings in this study have shown the evidence that collaborative culture has a considerable influence on both aspects of innovation capability. Especially, empirical finding revealed that in contrast with the greater effect of TL on process innovation, collaborative culture has positive impacts on product innovation. The findings, therefore, have provided a clear and effective to follow each specific aspect of innovation capability. Consequently, these findings contribute to advancing the theory of innovation being straight forward.

\section{Research Limitation and Future Direction}

Beside significant contributions to the theory and practice, the paper also contains some certain limitations. First, this paper utilizes cross-sectional design, so it might express the cases that causal correlations might change in the long-time. Thus, longitudinal studies are required to surpass this restriction and consolidate the findings. Second, the sample size used in the study was small. Therefore, the results of the study may have certain differences from the population. Future studies need to use a larger sample size to test the correlation between factors and confirm the research results. Finally, key organization factors such as TL, HRM practices and collaborative culture are the crucial factors for firms to sustain competitive advantage. Future research should investigate their antecedents and consequences to bring deeper insight on the way to practice them for fostering better key organizational outcomes such as innovation and performance.

\section{Implications and Conclusions}

This study has significantly contributed to increasing the understanding on antecedents of innovation and advance the theory of innovation management. Indeed, by investigating the relationship between key organizational factors and two specific forms of innovation capability namely product and process innovation, the findings of study imply that organizational factors have different effects on certain aspects of innovation capacity. Specifically, this study emphasizes the greater effect of collaborative culture on product innovation compared to its effect on process innovation. In contrast, this study highlights the greater and more significant influence of TL on process innovation compared to its impacts on product innovation. In other words, this study has contributed to bringing deeper insights into the current literature on the specific and effective path to each aspect of innovation capability. 
Besides, "the majority of organizations in emerging and developing countries are small and mediumsized and lack capital and resources, so it is not feasible for firms in these nations to improve innovation capacity by huge investments in technological innovation" (Gui et al., 2021). Thus, by examining the effects of available and low-cost factors on organizational innovation capability of Vietnamese firms, the findings of this study imply that focusing on key and available factors such as practicing leadership, caring for HR practices, and fostering collaborative culture might be some of the most effective solutions for CEOs/managers of firms in developing countries like Vietnam to achieve the fruits of innovation and success.

Overall, this study has contributed to academic development by proposing a conceptual model to explain the relationship between key organizational factors (TL, HR practices, collaborative culture) and firm's innovation capability. The study also serves as a valuable reference source that provide useful initiative and guidance for CEOs and managers in Vietnamese firms to apply and practice aimed at increasing product and process innovation capability for Vietnamese firms.

\section{References}

Ab Rahman, M. R. Z. B., \& Jantan, A. H. B. (2020). Leadership Behaviour Influence Organisational Commitment, Organisational Culture and Job Satisfaction at Public University in Malaysia. Journal of International Business and Management, 3(2), 01-13.

Ahmad, S., Ali, N. A., Jantan, A. H., Bowyer, D., \& Reaz, M. (2020). Organizational effectiveness through transformational leadership and technology innovation: a systematic literature review and future research agenda. Journal of International Business and Management, 3(4), $1-17$.

Ahmed, F., Shahzad, K., Aslam, H., Bajwa, S. U., \& Bahoo, R. (2016). The role of collaborative culture in knowledge sharing and creativity among employees. Pakistan Journal of Commerce and Social Sciences (PJCSS), 10(2), 335-358.

Aman, Q., Noreen, T., Khan, I., Ali, R., \& Yasin, A. (2018). The Impact of Human Resource Management Practices on Innovative Ability of Employees Moderated by Organizational Culture. International Journal of Organizational Leadership, 7, 426-439.

Bass, B. M. (1999). Two decades of research and development in transformational leadership. European journal of work and organizational psychology, 8(1), 9-32.

Camelo-Ordaz, C., Garcia-Cruz, J., Sousa-Ginel, E., \& Valle-Cabrera, R. (2011). The influence of human resource management on knowledge sharing and innovation in Spain: the mediating role of affective commitment. The International Journal of Human Resource Management, 22(07), 1442-1463.

Cho, H., Lee, P., \& Shin, C. H. (2019). Becoming a sustainable organization: focusing on process, administrative innovation and human resource practices. Sustainability, 11(13), 3554.

Delery, J. E., \& Doty, D. H. (1996). Modes of theorizing in strategic human resource management: Tests of universalistic, contingency, and configurational performance predictions. Academy of management Journal, 39(4), 802-835.

Fornell, C., \& Larcker, D. F. (1981). Evaluating structural equation models with unobservable variables and measurement error. Journal of marketing research, 18(1), 39-50.

Gui, L., Lei, H., \& Le, P. B. (2021). Determinants of radical and incremental innovation: the influence of transformational leadership, knowledge sharing and knowledge-centered culture. European Journal of Innovation Management, https://doi.org/10.1108/EJIM-122020-0478 (In Press).

Ha, A. T. L., Phong, L. B., \& Hui, L. (2019). Leadership and Organizational Learning: The Determinants of Innovation Speed and Innovation Quality in Vietnamese Firms. Journal of Management and Strategy, 10(1), 29-37.

Ha, T. T., \& Le, P. B. (2021). What Are the Sources of Organizational Change Capability? The Role of Transformational Leadership and Organizational Justice. International Journal of Business Administration, 12(2). 
Hair, J. F., Black, W. C., Babin, B. J., Anderson, R. E., \& Tatham, R. L. (2006). Multivariate data analysis 6th Edition. New Jersey: Pearson Education.

Hogan, S. J., \& Coote, L. V. (2014). Organizational culture, innovation, and performance: A test of Schein's model. Journal of business research, 67(8), 1609-1621.

Hui, L., Phouvong, S., \& Phong, L. B. (2018). Transformational Leadership Facilitates Innovation Capability: The Mediating Roles of Interpersonal Trust. International Journal of Business Administration, 9(3), 1-9.

Iqbal, S., Rasheed, M., Khan, H., \& Siddiqi, A. (2020). Human resource practices and organizational innovation capability: role of knowledge management. VINE Journal of Information Knowledge Management Systems.

Kumar, G., Banerjee, R. N., Meena, P. L., \& Ganguly, K. (2016). Collaborative culture and relationship strength roles in collaborative relationships: a supply chain perspective. Journal of Business \& Industrial Marketing, 31(5), 587-599.

Le Ba, P. (2018). Research on the Relationship between Transformational Leadership and Knowledge Sharing: The Mediating Roles of Justice and Trust. PhD Thesis, Hunan University.,

Le Ba, P. (2021). Tăng cường khả năng đổi mới thanh đạm cho các doanh nghiệp Việt Nam: Vai trò của lãnh đạo chuyển đổi và khả năng quản trị tri thức của doanh nghiệp. Tạp chí Kinh tế và Phát triển(286), 68-77.

Le, B. P., Lei, H., Phouvong, S., Than, T. S., Nguyen, T. M. A., \& Gong, J. (2018). Self-efficacy and optimism mediate the relationship between transformational leadership and knowledge sharing. Social Behavior and Personality: an international journal, 46(11), 1833-1846.

Le, B. P., \& Tran, Q. T. (2020). Leadership Practice for Building Trust of Followers: Decisive Factors of Organizational Performance. SEISENSE Journal of Management, 3(2), 45-57.

Le, L. T. K., \& Le, P. B. (2021). Improving the Innovation Performance for Vietnamese Firm Based on Practices of Idealized Influence and Individualized Consideration: The Mediating Role of Knowledge Sharing. International Journal of Business Administration, 12(3), 75-85.

Le, P. B. (2020). How transformational leadership facilitates radical and incremental innovation: the mediating role of individual psychological capital. Asia-Pacific Journal of Business Administration, 12(3/4), 205-222.

Le, P. B., \& Lei, H. (2018a). The effects of innovation speed and quality on differentiation and lowcost competitive advantage: The case of Chinese firms. Chinese Management Studies, 12(2), 305-322.

Le, P. B., \& Lei, H. (2018b). Fostering knowledge sharing behaviours through ethical leadership practice: the mediating roles of disclosure-based trust and reliance-based trust in leadership. Knowledge Management Research \& Practice, 16(2), 183-195.

Le, P. B., \& Lei, H. (2018c). The mediating role of trust in stimulating the relationship between transformational leadership and knowledge sharing processes. Journal of Knowledge Management, 22(3), 521-537.

Le, P. B., \& Lei, H. (2019). Determinants of innovation capability: the roles of transformational leadership, knowledge sharing and perceived organizational support. Journal of Knowledge Management, 23(3), 527-547.

Le, P. B., Lei, H., Le, T. T., Gong, J., \& Ha, A. T. (2020). Developing a collaborative culture for radical and incremental innovation: the mediating roles of tacit and explicit knowledge sharing. Chinese Management Studies, 14(4), 957-975.

Le, P. B., Lei, H., \& Than, T. S. (2018). How leadership and trust in leaders forster employees' behavior toward knowledge sharing. Social Behavior and Personality: an international journal, 46(5), 705-720.

Lei, H., Do, N. K., \& Le, P. B. (2019). Arousing a positive climate for knowledge sharing through moral lens: the mediating roles of knowledge-centered and collaborative culture. Journal of Knowledge Management, 23(8), 1586-1604. 
Lei, H., Gui, L., \& Le, P. B. (2021). Linking transformational leadership and frugal innovation: the mediating role of tacit and explicit knowledge sharing. ournal of Knowledge Management (In press).

Lei, H., Ha, A. T. L., \& Le, P. B. (2019). How ethical leadership cultivates radical and incremental innovation: the mediating role of tacit and explicit knowledge sharing. Journal of Business \& Industrial Marketing, 35(5), 849-862.

Lei, H., Khamkhoutlavong, M., \& Le, P. B. (2021). Fostering exploitative and exploratory innovation through HRM practices and knowledge management capability: the moderating effect of knowledge-centered culture. Journal of Knowledge Management (In press).

Lei, H., Le, P. B., \& Nguyen, H. T. H. (2017). How Collaborative Culture Supports for Competitive Advantage: The Mediating Role of Organizational Learning. International Journal of Business Administration, 8(2), 73-85.

Lei, H., Leaungkhamma, L., \& Le, P. B. (2020). How transformational leadership facilitates innovation capability: the mediating role of employees' psychological capital. Leadership \& Organization Development Journal, 41(4), 481-499.

Lei, H., Nguyen, T. T., \& Le, P. B. (2019). How knowledge sharing connects interpersonal trust and innovation capability: The moderating effect of leadership support. Chinese Management Studies, 13(2), 276-298.

Lei, H., Phouvong, S., \& Le, P. B. (2019). How to foster innovative culture and capable champions for chinese firms: an empirical research. Chinese Management Studies, 13(1), 51-69.

Martín-de Castro, G., Delgado-Verde, M., Navas-López, J. E., \& Cruz-González, J. (2013). The moderating role of innovation culture in the relationship between knowledge assets and product innovation. Technological Forecasting and Social Change, 80(2), 351-363.

Nguyen, D. K., Phong, L. B., \& Hui, L. (2019). Creating Competitive Advantage for Vietnamese Manufacturing and Service Firms: The Role of Collaborative Culture and Innovation Capability. International Journal of Business Administration, 10(2), 32-42.

Nguyen, M. A. T., Lei, H., Vu, K. D., \& Le, P. B. (2018). The role of cognitive proximity on supply chain collaboration for radical and incremental innovation: a study of a transition economy. Journal of Business \& Industrial Marketing, 34(3), 591-604.

Nunnally, J. C., \& Bernstein, I. (1994). Elements of statistical description and estimation. Psychometric Theory 3 Edition, McGraw-Hill, New York.

Phong, L. B., Hui, L., \& Son, T. T. (2018). The mediating role of knowledge sharing in linking transformational leadership and innovation. The 5th IBSM International Conference on Business, Management and Accounting, Hanoi University of Industry, Vietnam. http://caalinteduorg.com/proceedings/ibsm5/HRM2-12.pdf.

Phong, L. B., \& Son, T. T. (2020). The Link Between Transformational Leadership and Knowledge Sharing: Mediating Role of Distributive, Procedural and Interactional Justice. Journal of Information Knowledge Management, 19(3), 2050020.

Scarbrough, H. (2003). Knowledge management, HRM and the innovation process. International Journal of Manpower, 24(5), 501-516.

Sengphet, P., Hui, L., \& Phong, L. (2019). The Pathway to Improve Innovation Capacity for Lao Firms: The Roles of Transformational Leadership and Psychological Resources of Employees. Journal of Business Administrative Studies, 5(2), 224-239.

Son, T. T., Phong, L. B., \& Loan, B. T. T. (2020). Transformational Leadership and Knowledge Sharing: Determinants of Firm's Operational and Financial Performance. Sage Open, 10(2), 2158244020927426.

Son, T. T., Thang, T. Q., Cung, N. H., \& Phong, L. B. (2019). Building competitive advantage for Vietnamese firms: the roles of knowledge sharing and innovation. International Journal of Business Administration, 10(4), 1-12.

Than, S. T., Le, P. B., \& Le, T. T. (2021). The impacts of high-commitment HRM practices on exploitative and exploratory innovation: the mediating role of knowledge sharing. VINE Journal of Information Knowledge Management Systems, https://doi.org/10.1108/VJIKMS10-2020-0196. 
Tian, M., Deng, P., Zhang, Y., \& Salmador, M. P. (2018). How does culture influence innovation? A systematic literature review. Management Decision, 56(5), 1088-1107.

Tran, A. P., \& Le, B. P. (2019). Giảng dạy khởi nghiệp và đổi mới sáng tạo trong bối cảnh xây dựng các "đại học khởi nghiệp". Tạp chí Khoa học và Công nghệ, 55, 126-132.

Van, N. T., Phong, L. B., \& Loan, L. T. (2018). Antecedents of Innovation Capability: The Role of Transformational Leadership and Organizational Learning. International Journal of Business Administration, 9(5), 1-10.

Yang, Z., Nguyen, V. T., \& Le, P. B. (2018). Knowledge sharing serves as a mediator between collaborative culture and innovation capability: an empirical research. Journal of Business \& Industrial Marketing, 33(7), 958-969.

Appendix 1. Scale of factors in the proposal research model

\begin{tabular}{|c|c|c|}
\hline Factors & Items & Source \\
\hline \multicolumn{3}{|c|}{ Transformational leadership } \\
\hline TL1 & $\begin{array}{l}\text { My supervisor can understand my situation and give me encouragement and } \\
\text { assistance }\end{array}$ & \multirow{8}{*}{$\begin{array}{l}\text { Lei et al. } \\
\text { (2021b) }\end{array}$} \\
\hline TL2 & My supervisor encourages me to take challenges & \\
\hline TL3 & I believe my supervisor can overcome any challenge at work & \\
\hline TL4 & $\begin{array}{l}\text { My supervisor encourages us to make efforts towards fulfilling the company } \\
\text { vision }\end{array}$ & \\
\hline TL5 & $\begin{array}{l}\text { My supervisor encourages me to think about problems from a new } \\
\text { perspective }\end{array}$ & \\
\hline TL6 & $\begin{array}{l}\text { My supervisor encourages me to rethink opinions that have never been } \\
\text { doubted in the past }\end{array}$ & \\
\hline TL7 & I believe I can complete my work under the leadership of my supervisor & \\
\hline TL8 & My supervisor spends time to understand my needs & \\
\hline \multicolumn{3}{|c|}{ Human Resource Management (HRM) } \\
\hline HRM1 & Our firm often emphasizes promotion from within & \multirow{6}{*}{$\begin{array}{l}\text { Camelo- } \\
\text { Ordaz et } \\
\text { al. } \\
(2011)\end{array}$} \\
\hline HRM2 & Performance appraisals in our firm include developmental feedback & \\
\hline HRM3 & $\begin{array}{l}\text { Selection process in our firm often assesses the ability to collaborate and } \\
\text { work in a team }\end{array}$ & \\
\hline HRM4 & Training activities focus on team building and interpersonal relations & \\
\hline HRM5 & Appraisals in our firm are often based on team performance & \\
\hline HRM6 & Appraisals often focus on employees' ability to work with others & \\
\hline \multicolumn{3}{|c|}{ Collaborative culture (CC) } \\
\hline $\mathrm{CC} 1$ & $\begin{array}{l}\text { Our firm has processes to gain knowledge on our suppliers, customers, and } \\
\text { partners }\end{array}$ & \multirow{8}{*}{$\begin{array}{l}\text { Le et al. } \\
(2020)\end{array}$} \\
\hline $\mathrm{CC} 2$ & Our firm can generate new knowledge from existing knowledge & \\
\hline $\mathrm{CC} 3$ & $\begin{array}{l}\text { Our firm has processes in place to distribute knowledge throughout the } \\
\text { organization }\end{array}$ & \\
\hline $\mathrm{CC} 4$ & $\begin{array}{l}\text { Our firm holds periodic meetings to inform employees about the latest } \\
\text { innovations }\end{array}$ & \\
\hline $\mathrm{CC} 5$ & $\begin{array}{l}\text { Our firm has formal processes to share the best practice among the different } \\
\text { fields of activities }\end{array}$ & \\
\hline CC6 & In our firm, knowledge is accessible to those who need it & \\
\hline $\mathrm{CC} 7$ & $\begin{array}{l}\text { Our firm has processes for using knowledge to develop new products or } \\
\text { services }\end{array}$ & \\
\hline $\mathrm{CC} 8$ & $\begin{array}{l}\text { Our firm has processes for using knowledge to develop new products or } \\
\text { services }\end{array}$ & \\
\hline
\end{tabular}




\begin{tabular}{|c|c|c|}
\hline Factors & Items & Source \\
\hline PDI1 & $\begin{array}{l}\text { Our company often develops new products and services well accepted by } \\
\text { the market }\end{array}$ & \multirow{6}{*}{$\begin{array}{l}\text { Yang et } \\
\text { al. } \\
(2018)\end{array}$} \\
\hline PDI2 & $\begin{array}{l}\text { A great majority of our company's profits are generated by the new products } \\
\text { and services developed }\end{array}$ & \\
\hline PDI3 & $\begin{array}{l}\text { The new products or services developed by our company always arouse } \\
\text { imitation from competitors. }\end{array}$ & \\
\hline PDI4 & $\begin{array}{l}\text { Our company can often launch new products or services faster than our } \\
\text { competitors }\end{array}$ & \\
\hline PDI5 & $\begin{array}{l}\text { Our company has better capability in R\&D of new products or services than } \\
\text { our competitors. }\end{array}$ & \\
\hline PDI6 & $\begin{array}{l}\text { Our company always develops novel skills for transforming old products } \\
\text { into new ones for market. }\end{array}$ & \\
\hline \multicolumn{3}{|c|}{ Process innovation capability } \\
\hline PCI1 & $\begin{array}{l}\text { Our company often tries different operation procedures to hasten the } \\
\text { realization of the company's goals. }\end{array}$ & \multirow{5}{*}{$\begin{array}{l}\text { Yang et } \\
\text { al. } \\
(2018)\end{array}$} \\
\hline PCI2 & $\begin{array}{l}\text { Our company always acquires new skills or equipment to improve the } \\
\text { manufacturing operation or service process. }\end{array}$ & \\
\hline PCI3 & $\begin{array}{l}\text { Our company can develop more efficient manufacturing process or } \\
\text { operation procedure. }\end{array}$ & \\
\hline PCI4 & $\begin{array}{l}\text { Our company can flexibly provide products and services according to the } \\
\text { demands of the customers. }\end{array}$ & \\
\hline PCI5 & $\begin{array}{l}\text { The new manufacturing process or operation procedure employed by our } \\
\text { company always arouses imitation from competitors. }\end{array}$ & \\
\hline
\end{tabular}

